\title{
The benthic graptolite Sphenoecium mesocambricus (Öpik, 1933) from the Middle Cambrian of Krekling, Oslo Region, Norway
}

\author{
Hendrikus Markus Wolvers' \& Jörg Maletz ${ }^{2}$ \\ ${ }^{1}$ Brunel 19, 3641VG Mijdrecht, The Netherlands. \\ ${ }^{2}$ Freie Universität Berlin, Institut für Geologische Wissenschaften, Malteserstrasse 74-100, D-12249 Berlin, Germany.
}

E-mail corresponding author (Jörg Maletz): yorge@zedat.fu-berlin.de

\begin{abstract}
Specimens of the Middle Cambrian benthic graptolite Sphenoecium have been discovered at two levels in the Alum Shale Formation at Krekling, Oslo Region, Norway. The material originated from an interval in the Goniagnostus nathorsti Biozone (upper Drumian stage of the Cambrian System) and represents only the second record of this genus from Norway. The specimens show the tubarium development more clearly than the type material of Sphenoecium mesocambricus, which was found in the same general region. Sphenoecium mesocambricus has a tubarium with slender creeping tubes, branching at close distances, and considerably widening erect thecal tubes with straight apertures. A much more slender specimen belonging to the same genus was also found, but cannot be referred to a described species.
\end{abstract}

Keywords: Cambrian, Pterobranchia, Graptolithina, Sphenoecium

Received 19. April 2016 / Accepted 6. August 2016 / Published online 1. October 2016

\section{Introduction}

The Middle Cambrian graptolite Sphenoecium mesocambricus (Öpik, 1933) is one of the oldest benthic graptolites ever documented (see Maletz, 2014; Maletz \& Steiner, 2015). Öpik (1933) originally described the species from the Paradoxides Shale of Krekling, based on a single complete specimen and a number of additional small fragments. He clearly identified it as a graptolite and named it Dendrograptus mesocambricus, even though little detail was recognisable in the available material. Maletz \& Steiner (2015) redescribed the specimen and recognised a phosphatic brachiopod in the centre as the point of attachment of the specimen. Öpik (1933) originally reported the specimen to be associated with Ptychagnostus punctuosus (Angelin, 1851) and referred the material to the Paradoxides davidis Zone. A reidentification of the trilobites demonstrated the presence of Peronopsis fallax (Linnarsson, 1869), Goniagnostus nathorsti (Brøgger, 1878) and Lejopyge sp. on the slab (Maletz \& Steiner, 2015, p. 1088), indicating the Goniagnostus nathorsti Zone.

Additional material had never been collected from the region and the holotype remained the only available specimen of this species. Bengtson \& Urbanek (1986) described some much better preserved material of a Middle Cambrian benthic graptolite from the Eccaparadoxides pinus Zone of Närke, Sweden as Rhabdotubus johanssoni. The authors demonstrated the presence of irregular fuselli on the erect and creeping tubes and of branching in the creeping tubes, thus verifying the graptolitic origin of the material. Maletz \& Steiner (2015) synonymised Rhabdotubus johanssoni with Dendrograptus mesocambricus and referred the material to the genus Sphenoecium Chapman \& Thomas,

Wolvers, H.M. \& Maletz, J. 2016: The benthic graptolite Sphenoecium mesocambricus (Öpik, 1933) from the Middle Cambrian of Krekling, Oslo Region, Norway. Norwegian Journal of Geology 96, 311-318. http://dx.doi.org/10.17850/njg96-4-02. 
1936. The authors were able to show a vague indication of fusellar development also in type material of Sphenoecium mesocambricus from Krekling.

\section{Locality}

Krekling in the Eiker-Sandsvær area of the Oslo Region in southern Norway is well known through the investigation of the Cambrian succession and the description of biostratigraphically important agnostid trilobites from the Cambrian Alum Shale Formation by Brøgger (1878, 1882a, b). Brøgger (1878, p. 32) indicated the presence of c. $28 \mathrm{~m}$ of black shales of the Middle Cambrian Paradoxides paradoxissimus and Paradoxides forchhammeri zones at Krekling and described a rich trilobite fauna. Some of the trilobite species were revised by Bruton (1999) and Høyberget \& Bruton (2008), who reillustrated some of the original specimens of Brøgger (1878). Brøgger also described a small number of hyolithids, revised by Berg-Madsen \& Malinky (1999) and Malinky \& Berg-Madsen (1999). Outcrops are poor in overgrown ravines, and commonly consist of temporary exposures of few metres of section.
Öpik (1933) collected a single specimen of a benthic graptolite, identified as Sphenoecium mesocambricus, from the Krekling area and illustrated the exact locality in a photograph. He stated that the locality is opposite to and a few tens of metres from the train station (Fig. $1)$. The locality is now a protected nature reserve. The additional material described herein was collected from two localities along the slope not far from Öpik's locality (Fig. 1). Brøgger (1882a) described additional outcrops in the same unit farther away from the train station, but it has proven difficult to retrace his steps and to identify the smaller outcrops. Moreover, postglacial alluvium and vegetation generally makes an interpretation of the relationship between these outcrops impossible.

\section{Trilobite biostratigraphy}

As there are very few records of dendroid graptolites from Cambrian rocks, and most of these are poorly dated (see Maletz, 2014), a precise investigation of the faunal record associated with early dendroid graptolites from the Cambrian System is essential to understand the origin and early evolution of this group. The trilobite

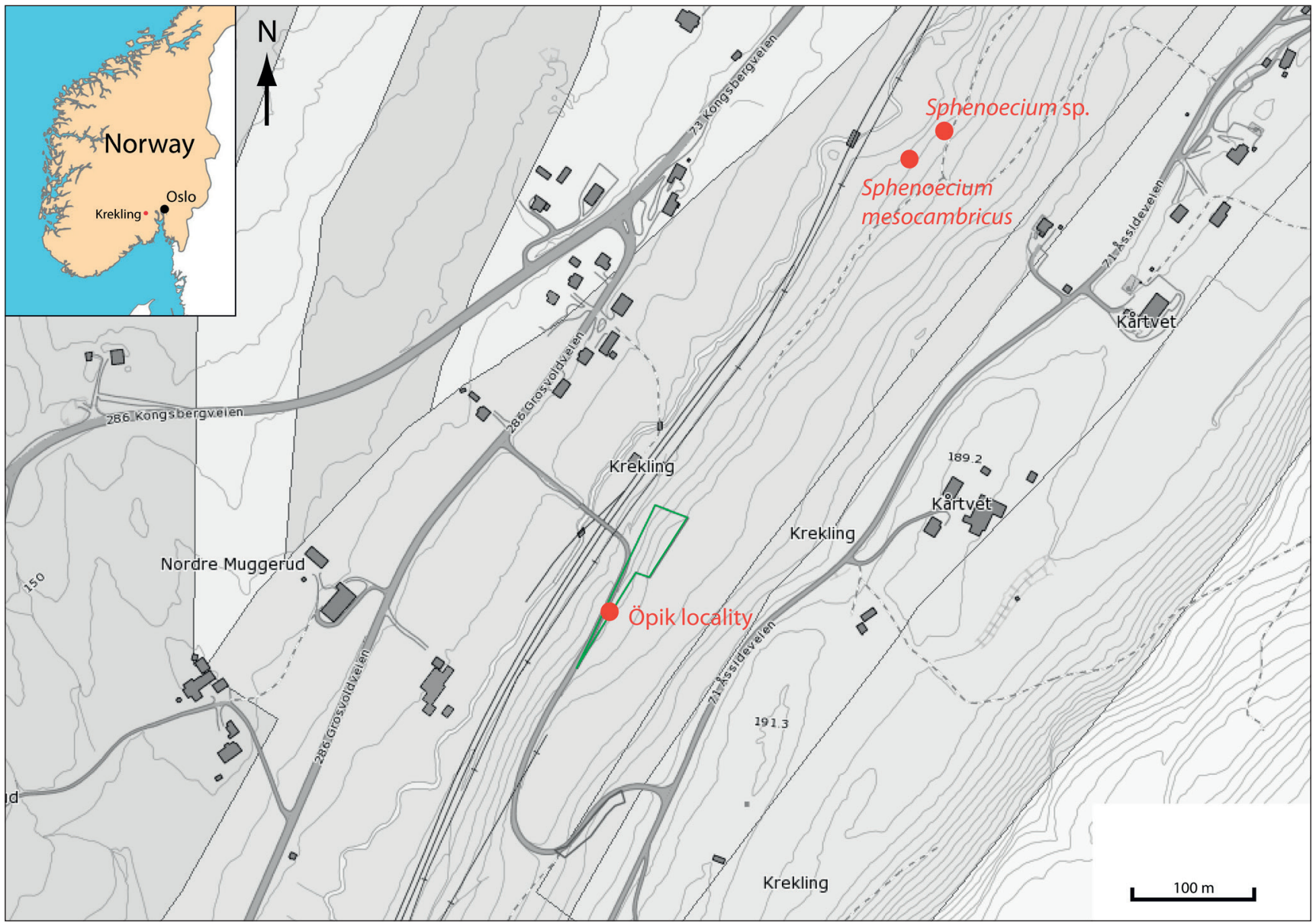

Figure 1. Map of the Krekling area and the locations of the investigated outcrops. Map based on http://geo.ngu.no/kart/berggrunn/. 


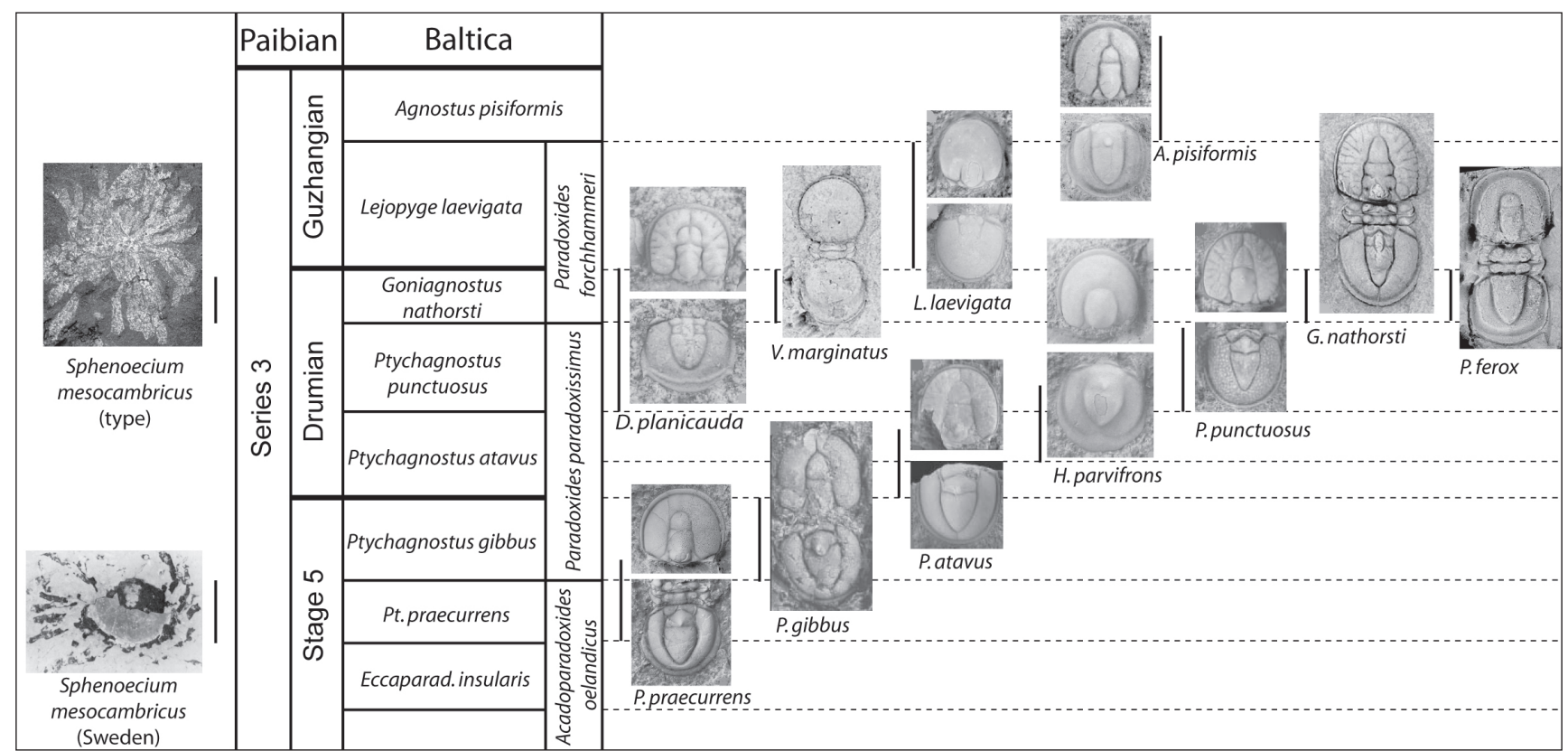

Figure 2. Agnostid biostratigraphy of Cambrian Series 3 (based on Axheimer et al., 2006; Peng et al., 2012). Trilobite specimens from Bengtsson (1999), Bruton (1999), Axheimer (2006), Axheimer et al. (2006), Høyberget \& Bruton (2008), Weidner \& Ebbestad (2014); graptolites from Bengtson \& Urbanek (1986) and Maletz \& Steiner (2015). Illustrations not to scale. Trilobite ranges largely based on data in Høyberget \& Bruton (2008).

biostratigraphy of the Middle Cambrian Series 3 (Fig. 2) is most precisely defined by the FADs of a number of agnostids; these have commonly been used to define chronostratigraphic units in the Cambrian (e.g., Peng \& Robison, 2000; Peng et al., 2004, 2009a, b, 2012, 2014; Babcock et al., 2005, 2007, 2015). Fortunately, Cambrian agnostids are often abundant in shaly environments and can be associated with fossil graptolites. Thus, they can be used for precise dating of early graptolitiferous successions. Due to their wide distribution, these trilobites can also generally be used for intercontinental correlations (see Ahlberg, 2003; Babcock et al., 2005; Peng \& Babcock, 2011; Peng et al., 2012).

Quite a number of relatively recent papers have referred to the biostratigraphic distribution of agnostids in Scandinavia, providing precise biostratigraphic data and revising the agnostid taxonomy (Axheimer \& Ahlberg, 2003; Axheimer et al., 2006; Ahlberg et al., 2007, 2009; Høyberget \& Bruton, 2008). Axheimer \& Ahlberg (2003) described the succession in the Almbacken drillcore of Scania, which includes the Ptychagnostus gibbus to Lejopyge laevigata zones. Axheimer et al. (2006) defined the Lejopyge laevigata Biozone at the FAD of Lejopyge laevigata in Scandinavia and, thus, extended the zone to include the traditional Scandinavian Solenopleura? brachymetopa Biozone. Axheimer et al. (2006, p. 448) placed the base of the overlying Agnostus pisiformis zone at the LAD of Lejopyge laevigata, which is slightly above the FAD of Agnostus pisiformis. The Scandinavian Hypagnostus parvifrons zone is regarded as the upper part of the international Ptychagnostus atavus zone (Westergård, 1946; Ahlberg, 1989; Axheimer \& Ahlberg, 2003; Peng et al., 2009b).
Høyberget \& Bruton (2008) described the agnostid succession from a number of sections in Norway and commented upon the section at Krekling described by Brøgger (1878). The authors illustrated the fossil succession from a drillcore at Stavlum, c. $2.5 \mathrm{~km}$ northeast of Brøgger's (1878) section, and redescribed many of the taxa of Brøgger (1878). They did not, however, revise the agnostid biostratigraphy of the Krekling locality.

The earliest agnostids in the Krekling succession belong to Ptychagnostus gibbus according to Brøgger (1878), indicating the Ptychagnostus gibbus zone, but the base is not seen in this succession. Agnostids from this zone and the Ptychagnostus atavus Zone were not found at Stavlum, but Høyberget \& Bruton (2008, p. 8, fig. 4) reported Hypagnostus parvifrons and Ptychagnostus affinis, which they referred to the top of the Ptychagnostus atavus Zone. Hypagnostus parvifrons appears to be found in the upper Ptychagnostus atavus to Ptychagnostus punctuosus zone of Brøgger's succession (see Fig. 3).

Høyberget \& Bruton (2008) recognised the base of the Goniagnostus nathorsti Biozone at $84.93 \mathrm{~m}$, but did not separate the Goniagnostus nathorsti and Lejopyge laevigata biozones at Stavlum. The top of the Lejopyge laevigata Biozone was indicated by the FAD of Agnostus pisiformis at $68.30 \mathrm{~m}$ The thickness fits nicely with the succession shown by Brøgger (1878, table 1), in which the FAD of Goniagnostus nathorsti is about $10 \mathrm{~m}$ above the base of the Alum Shale Formation. The appearance and range of Lejopyge laevigata may be problematic, as Brøgger (1878) lumped a number of taxa under this name (see Høyberget \& Bruton, 2008). Thus, the base 


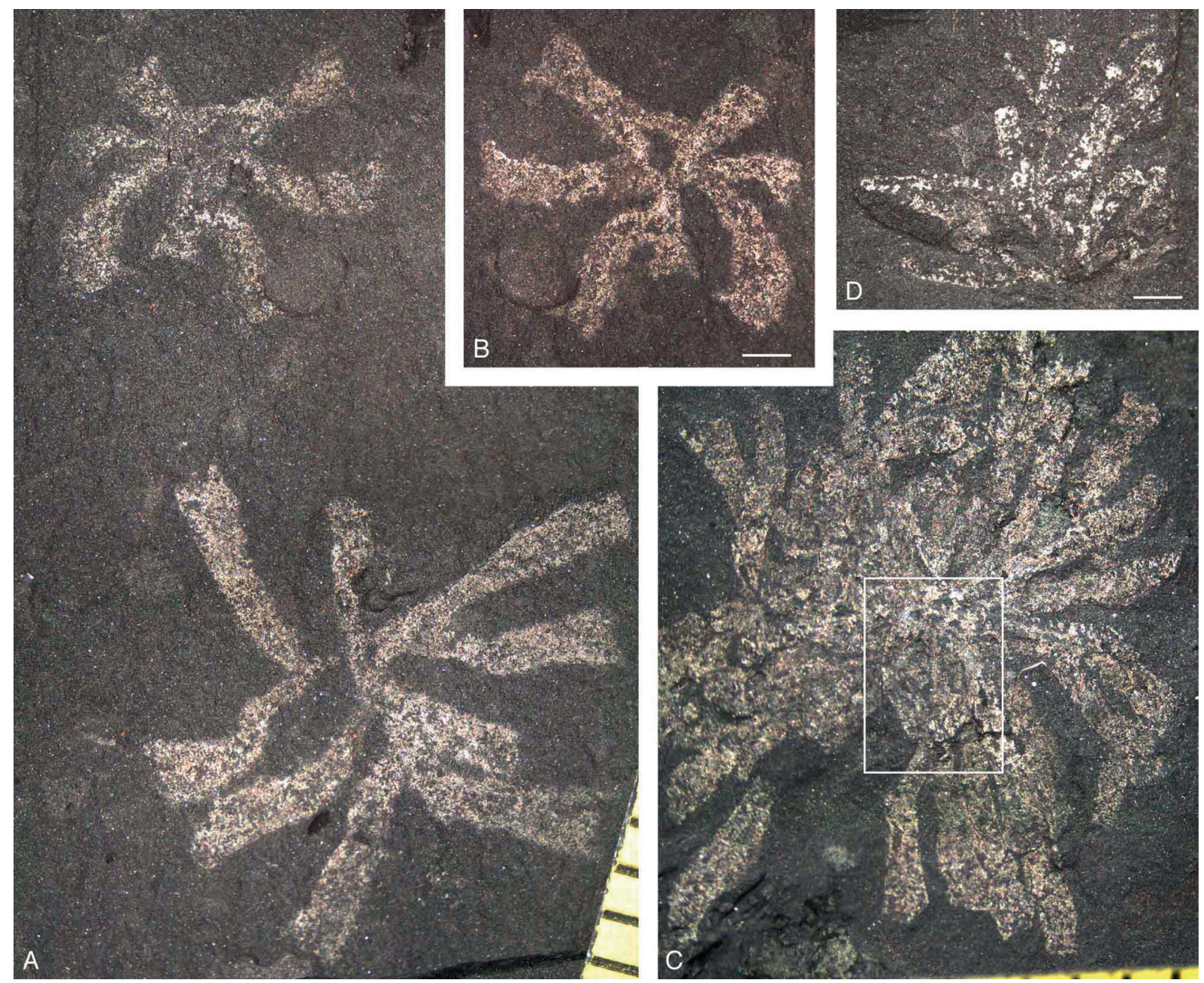

Figure 3. (A) Sphenoecium mesocambricus (Öpik, 1933), PMO 229.833/1-2, two associated specimens in dorso-ventral view. (B) PMO 229.834/2, counterpart of upper specimen in (A). (C) PMO 40.692, holotype of Sphenoecium mesocambricus (Öpik, 1933), showing phosphatic brachiopod in centre. (D) Sphenoecium sp., PMO 229.835/1, specimen in lateral preservation. All scale bars are $1 \mathrm{~mm}$.

of the Lejopyge laevigata zone is uncertain. According to Høyberget \& Bruton (2008, p. 8), a more precise biozonation is not possible, as the flattened trilobites in the Alum Shale Formation commonly do not show any diagnostic features.

The type specimen of Sphenoecium mesocambricus is associated with a number of trilobites, based on which Maletz \& Steiner (2015, fig. 11) referred the specimen to the Goniagnostus nathorsti Zone. The specimen is here referred to the interval of the upper Drumian, or the Goniagnostus nathorsti Biozone. Öpik (1933) originally identified the most common trilobites as Agnostus punctuosus, thus referring the material to an older biozone. A reidentification of the specimens refers the material to Goniagnostus nathorsti (Brögger, 1878), Peronopsis ferox (Tullberg, 1880) and Lejopyge calva Robison, 1964. According to the ranges provided by Høyberget \& Bruton (2008), this association clearly identifies the Goniagnostus nathorsti Biozone.
The type material of Rhabdotubus johanssoni Bengtson \& Urbanek (1986) originated from the Ptychagnostus praecurrens Biozone of Närke, Sweden (Fig. 2). This biozone is not recorded from the Krekling locality. Bengtson \& Urbanek (1986, p. 294) did not discuss in detail the associated trilobite fauna, but mentioned Acadoparadoxides (Baltoparadoxides) ex. gr. oelandicus (Sjögren, 1872) and Ellipsocephalus polytomus Linnarsson, 1877 as the most common species. Laibl et al. (2015) recently described Ellipsocephalus polytomus and indicated its occurrence in the provisional Cambrian Stage 5, the Acadoparadoxides pinus Zone in the polymerid zonation and the Ptychagnostus praecurrens Zone in the agnostid zonation of the Acadoparadoxides (Baltoparadoxides) oelandicus Superzone. Thus, the material of Rhabdotubus johanssoni is clearly older than the Krekling specimens. 


\section{The new material}

Three new specimens of the pterobranch genus Sphenoecium Chapman \& Thomas, 1936, were collected from the Middle Cambrian Goniagnostus nathorsti Biozone of the Alum Shale Formation of Krekling. The material can be referred to two different taxa on the basis of the dimensions of their thecal tubes.

\section{Taxonomy}

Phylum Hemichordata Bateson, 1885

Class Pterobranchia Lankester, 1877

Subclass Graptolithina Bronn, 1849

Family Rhabdopleuridae Fowler, 1892

Genus Sphenoecium Chapman \& Thomas, 1936

\section{Sphenoecium mesocambricus (Öpik, 1933)}

(Fig. 3A-C)

1933 Dendrograptus mesocambricus Öpik, p. 8, fig. 1. 1986 Rhabdotubus johanssoni Bengtson \& Urbanek, p. 296, figs. 1-9.

2015 Sphenoecium mesocambricus (Öpik), Maletz \& Steiner, p. 1099, figs. 14A-D.

Two new specimens of Sphenoecium mesocambricus (PMO 229.833, PMO 229.834) were collected at a locality in close proximity to Öpik's original locality (see Fig. 1). The locality coordinates are N59 $40.335^{\circ}$, E009 $46.248^{\circ}$ and the elevation is $140 \mathrm{~m}$. The specimens are well preserved, but flattened and show some details of the tubarium development. On the slabs (PMO 229.833 and PMO 229.834) the specimens are associated with remains of hyolithids (Fig. 4H-I) and agnostid trilobites (Fig. 4A-C, E).

Description. Both colonies are small and completely flattened. Part of the silvery-shining, somewhat thermally altered fusellum is preserved (see Maletz \& Steiner, 2015), but fusellar construction is not visible. The colonies are up to $13 \mathrm{~mm}$ in diameter and show a circular form, which may be based on the small size and the original attachment point. Three or four tubes appear to originate from a common point and branch further at close distances of less than $1 \mathrm{~mm}$. The tubes are initially about $0.3-0.4 \mathrm{~mm}$ wide and an increase in tube width is not seen in the encrusting, creeping parts. Individual erect tubes slowly widen to about $1.2-1.3 \mathrm{~mm}$ at the aperture. The apertures are straight and simple. None of the observed tubes is more than $5 \mathrm{~mm}$ long, but it cannot be ruled out that the tubes are incomplete or immature. The largest specimen bears nine tubes of various lengths.

Remarks. The original attachment of the colonies cannot be estimated, as neither of the two new specimens show any indication of attachment, but still a common point from which the growth of the colony started is visible. The type specimen of Sphenoecium mesocambricus was found to be attached to a phosphatic brachiopod (Fig. 3C), as are many specimens described by Bengtson \& Urbanek (1986) as Rhabdotubus johanssoni. The holotype consists of numerous radiating thecal tubes, but interconnections between the tubes are not recognisable in the specimen, even though indications of branching of the tubes are visible. The specimen bears at least 30-35 thecal tubes that are apparently connected at the brachiopod shell in the centre (Fig. 3C). The new specimens clearly show the branching of the creeping, repent tubes which confirm the assignment of the taxon to the colonial Pterobranchia.

The new specimens are similar in their development and size to Sphenoecium fillicoides (Chapman, 1917) from the Cambrian of Victoria, Australia, but differences can be seen in the dimensions of the tubaria. The age of the Australian material was only indirectly established when Thomas \& Singleton (1956) correlated the Heathcote fauna with the Ptychagnostus gibbus zone. As only a few specimens of Sphenoecium species have been collected, it is impossible at the moment to estimate the intraspecific variation of these taxa. Therefore, all the previously described taxa (see Maletz \& Steiner, 2015, for an overview) are herein regarded as separate and valid taxa.

Associated fauna. The specimens are preserved in a fossil-rich, bituminous, black shale in which other fossils are not uncommon, but generally are fragmentary where they occur. Remains of trilobite exuviae are the most common and a small number of agnostid trilobites have been identified in association with the pterobranch remains. They belong to Diplagnostus planicauda (Angelin, 1851) and Valenagnostus marginatus (Brøgger, 1878). Diplagnostus planicauda was not mentioned or illustrated by Brøgger (1878) and was first described and illustrated from Norway by Høyberget \& Bruton (2008). A single, poorly preserved complete specimen (Fig. 4A) and a second pygidium (Fig. 4B-C: counterparts) was found. Valenagnostus marginatus is present as a single pygidium (Fig. 4E).

\section{Sphenoecium sp.}

(Fig. 3D)

The specimen originates from a level several metres above the specimens of Sphenoecium mesocambricus. The coordinates may be given as N59 $40.342^{\prime}$, E009 $46.279^{\circ}$. The elevation is 148 metres.

Description. A single laterally preserved specimen without counterpart (Fig. 3D) is available from Krekling. Branching in this specimen appears to be irregularly developed, but this may be due to the unfortunate preservation in which the thecae overlap considerably and many parts are covered. The colony is about $7 \mathrm{~mm}$ 

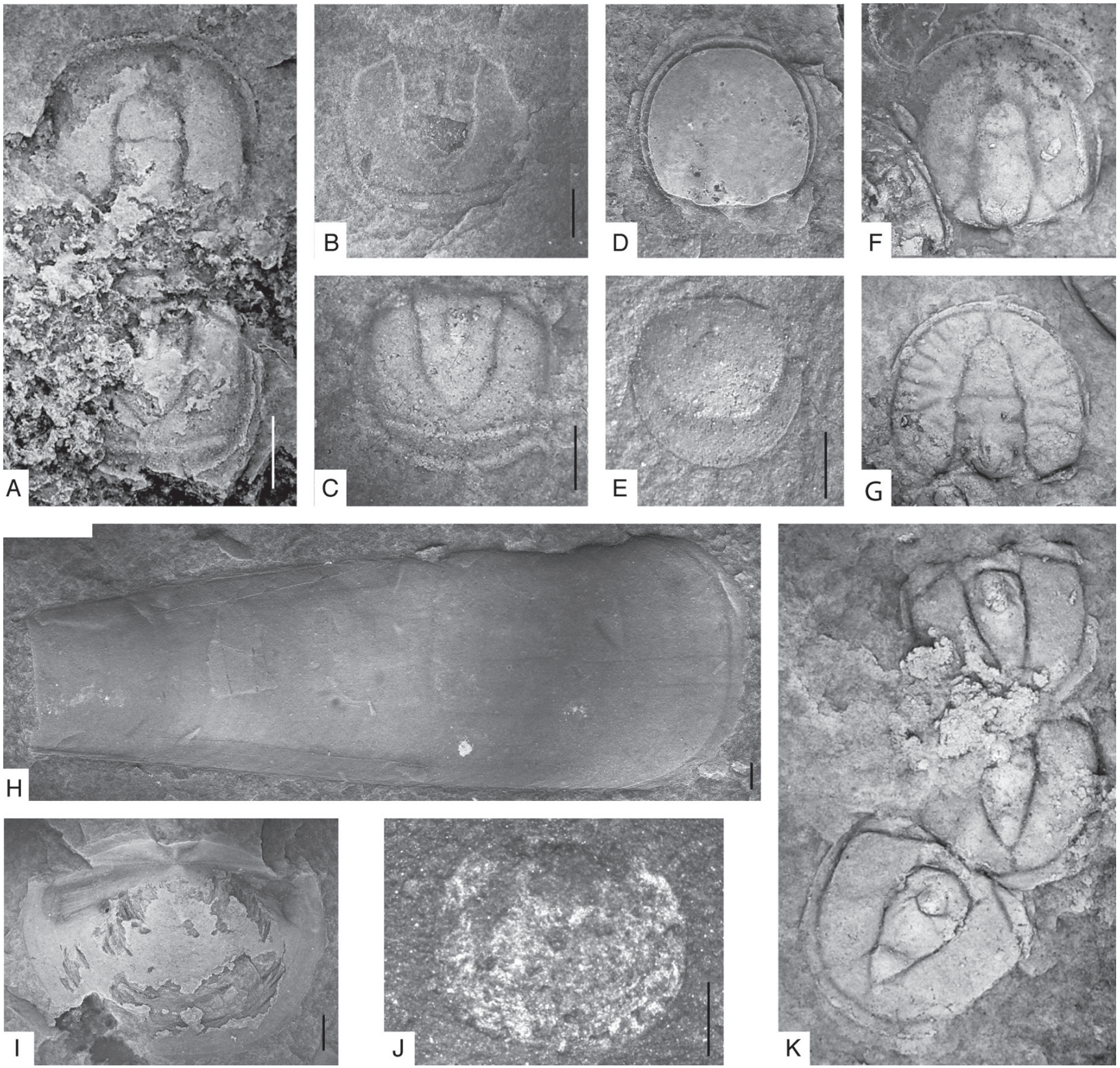

Figure 4. Associated fossils. (A-C) Diplagnostus planicauda (Angelin, 1851). (A) PMO 229.834/3, complete specimen, with poor preservation of body segments. (B) PMO 229.833/3, mould. (C) PMO 229.834/3, latex cast of specimen. (D) Lejopyge calva Robison, 1964, cranidium, PMO 27.865c (identified as Leiopyge sp. in Maletz \& Steiner, 2015). (E) Valenagnostus marginatus (Brøgger, 1878) pygidium, PMO 229.833/4. (F) Peronopsis ferox (Tullberg, 1880), PMO 40.692, cranidium. (G, K) Goniagnostus nathorsti (Brøgger, 1878), cranidium (G) and several pygidia (K) on PMO 40.692. (H-I) Nevadotheca tenuistriata (Linnarsson, 1871). (H) conch, PMO 229.835/2. (I) PMO 229.835/3, operculum. (J) Phosphatic brachiopod indet., PMO 229.835/4. Trilobite identifications by Per Ahlberg (pers. comm., 2016) and Magne Høyberget (pers. comm., 2016). (A-I, K) are coated with ammonium chloride. All scale bars are $1 \mathrm{~mm}$.

wide and 5-6 mm high, but measurements are difficult due to the poor preservation. The individual thecal tubes are about $0.4-0.5 \mathrm{~mm}$ wide and more than $3 \mathrm{~mm}$ long. There are c. 16-20 thecal tubes visible, but most of them are partly covered by others and the exact number is impossible to tell.

Remarks. The specimen is not referred to Sphenoecium mesocambricus, as it differs considerably in size from that species. Due to the poor preservation, no attempt is made to provide a more precise assignment.
Associated fauna. Sphenoecium sp. is associated with some poorly preserved phosphatic brachiopods, hyolithid fragments and some very abraded, indeterminable agnostids, which are not age constraining. Two specimens of hyolithids are present on the slabs (Fig. $4 \mathrm{H}$, I). According to the revision of the Krekling material of hyolithids by Berg-Madsen \& Malinky (1999), they may be referred to Nevadotheca tenuistriata (Linnarsson, 1871). Brøgger (1878, pl. 4, fig. 13a, b) described and illustrated comparable material from Krekling. He also illustrated Hyolithes socialis Linrs.? and a new species 
Hyolithes plicatus, which may be related to the genus Contitheca Syssoiev, 1968 (see Berg-Madsen \& Malinky, 1999, p. 864). Holm (1893) referred Brøgger's (1878) Hyolithes socialis Linrs.? to Hyolithes(?) broeggeri $\mathrm{n}$. sp., but did not describe the species (Malinky \& BergMadsen, 1999, p. 37).

Acknowledgements. Agnes Lyche Melvaer, Kirsten Lyche Baastad and Maximo Alfonso Rojo are thanked for their hospitality in providing accommodation to HMW during the geological field trips to Norway in 2013 and 2014. HMW acknowledges the assistance and company of Erik Brett Jacobsen, Jens Koppka, Maximo Alfonso Rojo and Roger Smeets in the field. Roger Smeets and Maximo Alfonso Rojo collected and donated the specimens to the authors. D. L. Bruton (PMO Oslo, Norway) is acknowledged for his encouragement to HMW to continue the exploration of the Cambrian succession in the Krekling area. JM acknowledges the support of F.-J. Lindemann (PMO, Oslo, Norway) in obtaining type and other material for comparison from the Natural History Museum, Oslo, Norway. Per Ahlberg (Lund, Sweden) and Magne Høyberget (Mandal, Norway) provided additional information on agnostid biostratigraphy and species identifications. The manuscript was improved considerably through the reviews of Magne Høyberget and Lucy Muir.

\section{References}

Ahlberg, P. 1989: Cambrian shelly fauna and biostratigraphy of Scandinavia. Lund Publications in Geology 141, 1-47.

Ahlberg, P. 2003: Trilobites and intercontinental tie points in the Upper Cambrian of Scandinavia. Geologica Acta 1, 127-134.

Ahlberg, P., Axheimer, N. \& Robison, R.A. 2007: Taxonomy of Ptychagnostus atavus: a key trilobite in defining a global Cambrian stage boundary. Geobios 40, 709-714.

Ahlberg, P., Axheimer, N., Babcock, L.E., Eriksson, M.E., Schmitz, B. \& Terfelt F. 2009: Cambrian high-resolution biostratigraphy and carbon isotope chemostratigraphy in Scania, Sweden: first record of the SPICE and DICE excursions in Scandinavia. Lethaia 42, 2-16.

Angelin, N.P. 1851: Palaeontologia Suecica. Pars I: Iconographia crustaceorum formationis transitionis. Fascicule 1, Lund, 1-24. [Angelin, N. P. 1851-1878: Palaeontologia Scandinavica. Pars. 1. Crustacea Formationis Transitionis fase. 1 (1851) - Palaeontologia Suecica, 1-24, Plate 1-24; fase. 2 (1854) - Palaeontologia Scandinavica, iix, 21-29, Plate 25-41; republished in combined and revised form (1878) by Lindström, G. (Ed.): x+96, 41 Plates. ]. Norstedt \& Soner, Stockholm].

Axheimer, N. 2006: The lower and middle Cambrian of Sweden: trilobites, biostratigraphy and intercontinental correlation. $\mathrm{PhD}$ thesis, Lund University, $90 \mathrm{pp}$.

Axheimer, N. \& Ahlberg, P. 2003: A core drilling through Cambrian strata at Almbacken, Scania, S. Sweden: trilobites and stratigraphical assessment. Geologiska Föreningen i Stockholm Förhandlingar $125,139-156$.

Axheimer, N., Eriksson, M.E., Ahlberg, P. \& Bengtsson, A. 2006: The Middle Cambrian cosmopolitan key species Lejopyge laevigata and its biozone: new data from Sweden. Geological Magazine 143, 447-455.

Babcock, L.E., Peng, S.C., Geyer, G. \& Shergold, J.H. 2005: Changing perspectives on Cambrian chronostratigraphy and progress toward subdivision of the Cambrian System. Geosciences Journal 9, 101106.

Babcock, L.E., Robison, R.A., Rees, M.N., Peng, S.C. \& Saltzman, M.R. 2007: The Global boundary Stratotype Section and Point (GSSP) of the Drumian Stage (Cambrian) in the Drum Mountains, Utah, USA. Episodes 30, 85-95.
Babcock, L.E., Peng, S.-C., Brett, C.E., Zhu, M.-Y., Ahlberg, P., Bevis, M. \& Robison, R.A. 2015: Global climate, sea level cycles, and biotic events in the Cambrian Period. Palaeoworld 24, 5-15.

Bateson, W. 1885: The later stages in the development of Balanoglossus kowalevskii, with a suggestion as to the affinities of the Enteropneusta. Quarterly Journal of Microscopical Science 25, 81-122.

Bengtson, S. \& Urbanek, A. 1986: Rhabdotubus, a Middle Cambrian rhabdopleurid hemichordate. Lethaia 19, 293-308.

Bengtsson, A. 1999: Trilobites and bradoridid arthropods from the Middle and Upper Cambrian at Gudhem in Västergötland, Sweden. Examensarbete i geologi vid Lunds Universitet, Historisk geologi och paleontologi 106, 1-21.

Berg-Madsen, V. \& Malinky, J.M. 1999: A revision of Holm's mid and late Cambrian hyoliths of Sweden. Palaeontology 42, 841-885.

Bronn, H.G. 1849: Handbuch der Geschichte der Natur. Dritter Band, Zweite Abtheilung. II. Theil: Organisches Leben (Schluß). Index palaeontologicus oder Ueberblick der bis jetzt bekannten fossilen Organismen. Schweizerbart'sche Verlagsbuchhandlung, Stuttgart, $1106 \mathrm{pp}$.

Bruton, D.L. 1999: Notes on Brøgger's type species of agnostid trilobite genera. Geologiska Föreningens i Stockholm Förhandlingar 121, 337-341.

Brøgger, W.C. 1878: Om Paradoxidesskifrene ved Krekling. Nyt Magazin for Naturvidenskaberne 24, 18-88.

Brøgger, W.C. 1882a: Paradoxides oelandicus-nivået ved Ringsaker i Norge. Geologiska Föreningens i Stockholm Förhandlingar 6, 143148, pl. 8.

Brøgger, W.C. 1882b: Die silurischen Etagen 2 und 3 im Kristianiagebiet und auf Eker. Universitetsprogramm, pp. 1-376.

Chapman, F. 1917: Report on Cambrian fossils from Knowley East, near Heathcote. Geological Survey of Victoria Records 4, 87-102, pls. 6-7.

Chapman, F. \& Thomas, D.E. 1936: The Cambrian Hydroidea of the Heathcote and Monegeeta Districts. Proceedings of the Royal Society of Victoria New Series 48, 193-212.

Fowler, G.H. 1892: The morphology of Rhabdopleura normani Allm.. In : Leuckarts, G.R. (ed.): Festschrift zum siebzigsten Geburtstage Rudolf Leuckarts, Engelmann, Leipzig, pp. 293-297.

Holm, G. 1893: Sveriges Kambrisk-Siluriska Hyolithidæ och Conulariidæ. Sveriges Geologiska Undersökning Series C112, 1-172.

Høyberget, M. \& Bruton, D.L. 2008: Middle Cambrian trilobites of the suborders Agnostina and Eodiscina from the Oslo Region. Palaeontographica A286, 1-87, 12 pls.

Laibl, L., Fatka, O., Budil, P., Ahlberg, P., Szabad, M., Vokáč, V. \& Kozák, V. 2015: The ontogeny of Ellipsocephalus (Trilobita) and systematic position of Ellipsocephalidae. Alcheringa 39, 477-487.

Lankester, E.R. 1877: Notes on the embryology and classification of the animal kingdom: comprising a revision of speculations relative to the origin and significance of the germ-layers. Quarterly Journal of Microscopical Science New Series 17, 399-454.

Linnarsson, J.G.O. 1869: Om Vestergotlands Cambriska och Siluriska aflagringar. Kongliga Svenska Vetenskapsakademiens-Handlingar 8, $1-89$.

Linnarsson, J.G.O. 1871: Om några försteningar från Sveriges och Norges "Primordialzon". Öfversigt af Kongliga VetenskapsAkademiens Förhandlingar 6, 789-796.

Linnarsson, J.G.O. 1877: Om faunan i lagran med Paradoxides olandicus. Sveriges Geologiska Undersokning C22, 1-24, 2 pls.

Maletz, J. 2014: The Classification of the Graptolithina Bronn, 1849. Bulletin of Geosciences 89, 477-540. doi: 10.3140/bull.geosci.1465.

Maletz, J. \& Steiner, M. 2015: Graptolites (Hemichordata, Pterobranchia) preservation and identification in the Cambrian Series 3. Palaeontology 58, 1073-1107. doi: 10.1111/pala.12200.

Malinky, J.M. \& Berg-Madsen, V. 1999: A revision of Holm's early and early Mid Cambrian hyoliths of Sweden. Palaeontology 42, 25-65.

Öpik, A. 1933: Über einen kambrischen Graptolithen aus Norwegen. Norsk Geologisk Tidsskrift 13, 8-10. 
Peng, S. \& Robison, R.A. 2000: Agnostoid biostratigraphy across the Middle-Upper Cambrian boundary in Hunan, China. Memoirs of the Paleontological Society 53, 1-104.

Peng, S. \& Babcock, L.E. 2011: Continuing progress on chronostratigraphic subdivision of the Cambrian System. Bulletin of Geosciences 86, 391-396.

Peng, S., Babcock, L.E., Robison, R.A., Lin, H.L., Rees, M.N. \& Saltzman, M.R. 2004: Global Standard Stratotype-section and Point (GSSP) of the Furongian Series and Paibian Stage (Cambrian). Lethaia 37, 365-379.

Peng, S., Babcock, L.E., Zuo, J.X., Lin, H.L., Zhu, X.J., Yang, X.F., Robison, R.A., Chi, Y.P., Bagnoli, G. \& Chen, Y. 2009a: The Global boundary Stratotype Section and Point (GSSP) of the Guzhangian Stage (Cambrian) in the Wuling Mountains, northwestern Hunan, China. Episodes 32, 41-55.

Peng, S., Hughes, N.C., Heim, N.A., Sell, B.K., Zhu, X.J., Myrow, P.M. \& Parcha, S.K. 2009b: Cambrian trilobites from the Parahio and Zanskar valleys, Indian Himalaya. Journal of Paleontology 83, 1-95.

Peng, S., Babcock, L.E. \& Cooper, R.A. 2012: The Cambrian Period. In Gradstein, F.M., Ogg, J.G., Schmitz, M.D. \& Ogg, G.M. (eds.): The Geologic Time Scale 2012, Volume 2, Elsevier B.V., Amsterdam, pp. 437-488.

Peng, S., Babcock, L.E., Zhu, X., Zuo, J. \& Dai, T. 2014: A potential GSSP for the base of the uppermost Cambrian stage, coinciding with the first appearance of Lotagnostus americanus at Wa'ergang, Hunan, China. Geologiska Föreningens i Stockholm Förhandlingar 136, 208 213.

Robison, R.A. 1964: Late Middle Cambrian faunas from western Utah. Journal of Paleontology 38, 510-566.

Sjögren, A. 1872: Om några försteningar i Ölands Kambriska lager. Geologiska Föreningens i Stockholm Förhandlingar 1, 67-80, pl. 5.

Syssoiev, V.A. 1968: Stratigraphy and hyoliths of the oldest Lower Cambrian beds of the Siberian Platform. Yakutsky Filial, Sibirskoe Otdelenie, Akademii Nauk SSSR, 1-67. [In Russian].

Thomas, D.E. \& Singleton, O.P. 1956: The Cambrian stratigraphy of Victoria. Bureau of Mineral Resources, Geology and Geophysics of Australia Bulletin 49, 149-164.

Tullberg, S.A. 1880: Om Agnostus-arterna i de kambriska aflagringarne vid Andrarum. Sveriges Geologiska Undersökning C42, 1-37.

Weidner, T. \& Ebbestad, J. O. R. 2014. The early middle Cambrian agnostid Pentagnostus praecurrens (Westergård1936) from Sweden. Memoirs of the Association of Australasian Palaeontologists 45, 403419.

Westergård, A.H. 1946: Agnostidea of the Middle Cambrian of Sweden. Sveriges Geologiska Undersökning C477, 1-140. 